\title{
PLACENTAL HYPERTROPHY IN THE RAT INDUCED BY OVARIECTOMY
}

\author{
M. O. PULKKINEN* AND E. CSAPO \\ Department of Obstetrics and Gynecology, \\ Washington University School of Medicine, St. Louis, Missouri
}

(Received 21st Fune 1968, accepted 24th September 1968)

As documented in two recent articles, an effective 'luteo-placental shift' in the support of the maintenance of pregnancy is not restricted to the human species. Under appropriate experimental conditions, the rat (Csapo, 1967) and even the rabbit (Csapo \& Csapo, 1968) are capable of performing this shift and thus may sustain pregnancy after bilateral ovariectomy. The success of this regulatory change depends on the compensatory changes in the placenta. In both species, only those animals which responded to ovariectomy with distinct placental hypertrophy sustained pregnancy, while those which did not, showed premature delivery (Gsapo, 1967; Csapo \& Csapo, 1968). Placental hypertrophy in ovariectomized, gestagen-treated rats has also been recently observed by Van der Vies \& Feenstra (1967).

These observations focused attention on the regulatory significance of placental hypertrophy. It was of interest to determine (in addition to the histological evidence indicating genuine hypertrophy without hyperplasia) to what extent this placental weight increase is due to hydration. This was examined by measuring placental dry weight, in addition to wet weight.

A total of thirty-three Holtzman-bred, Sprague-Dawley, pregnant rats was studied. The animals were 80 to 90 days old, 200 to $230 \mathrm{~g}$ weight, mated with $\pm 3 \mathrm{hr}$ accuracy. In this strain, the placental weights between the 13th and 22nd days of pregnancy are so precisely controlled that they can be predicted with less than $\pm 5 \%$ accuracy.

Bilateral ovariectomy was carried out at the 13th to 14th days of gestation under ether anaesthesia with strictly sterile precautions. At this time the placentae weigh only 0.11 and $0.15 \mathrm{~g}$, respectively, so that these animals (unlike those 15 to 17 days pregnant) cannot effectively compensate for the sudden loss of luteal secretion. Their foetuses die in utero, within $48 \mathrm{hr}$, unless the mother is given progesterone. A 'decremental' progesterone-substitution therapy needs to be employed for 4 to 6 days as a temporary aid to maintenance of pregnancy (Csapo, 1967).

The experimental animals in this series received 'decremental' progesterone therapy $(4,3,2,1$ and $0.5 \mathrm{mg} /$ day) which was discontinued 3 to 4 days before term. Both the control and experimental animals were killed on the morning of the 22nd day, a few hours before delivery.

* Present address: Department of Obstetrics and Gynecology, University of Turku, Turku, Finland.

$\mathbf{E}$ 
A number of unselected placentae from each animal were quickly removed and separated with scissors from the foetal membranes and foetuses, blotted on tissue paper and weighed on a torsion balance. The wet weights were recorded. Subsequently all the 124 placentae studied were placed in the drying oven at $110^{\circ} \mathrm{G}$ to reach constant weight.

Table 1 shows that while the foetal weights of the control and experimental animals are the same, both the wet and dry weights of the placentae are significantly different $(P<0.001)$. Since the water content of the placentae in the experimental animals is only $1 \%$ greater, whereas the dry weight is $21 \%$ greater than that of the control animals, this weight increase is evidence of a genuine hypertrophy. It is of interest to note that similar water increase $(2 \%)$ was observed (Wendt, 1952) in hypertrophied skeletal muscle. Also, uterine protoplasmic increase and decrease were found (Reynolds, 1949) to coincide with hydration and dehydration.

TABLE 1

THE GHANGES IN WET AND DRY WEIGHTS OF THE RAT PLACENTA INDUCED BY OVARIECTOMY

\begin{tabular}{l|c|c}
\hline & $\begin{array}{c}\text { Control group* } \\
\text { Mean } \pm \text { S.E. }\end{array}$ & $\begin{array}{c}\text { Experimental group* } \\
\text { Mean } \pm S . E .\end{array}$ \\
\cline { 2 - 3 } Av. foetal weight (mg) & $6400 \pm 160$ & $6500 \pm 170$ \\
Av. placental wet weight (mg) & $541 \pm 14$ & $717 \pm 21$ \\
Av. placental dry weight $(\mathrm{mg})$ & $82 \pm 2.5$ & $99 \pm 3 \cdot 1$ \\
Av. water content (\%) & $84.9 \pm 0 \cdot 11$ & $85 \cdot 7 \pm 0 \cdot 12$ \\
Av. foetal-placental ratio & $12 \cdot 1 \pm 0 \cdot 16$ & $9 \cdot 5 \pm 0 \cdot 20$ \\
\hline
\end{tabular}

* Control group: eight animals, thirty-three placentae. Experimental group: twenty-five animals, eighty-one placentae. Histology and steroid chemistry were carried out on the placentae not examined here. The controls were normal pregnant rats. Experimental animals were ovariectomized at Days 13 to 14 of gestation and subsequently treated with 'decremental' progesterone (4 to $0.5 \mathrm{mg} /$ day, for 4 to 6 days). All animals were killed 8 to 9 days after ovariectomy, at Day 22. All differences tabulated between the control and experimental group are highly significant statistically $(P<0.001)$, except in foetal weights.

Since there was a distinct correlation here $(\mathbf{r}=+0.91 \pm 0.112, P<0.001)$, between the wet and dry weights of the placentae, the wet weights under these experimental conditions can be safely used for assessing the extent of hypertrophy. Similar studies are under way in the rabbit. Of further interest is the lowered foetal-placental ratio $(\mathrm{F} / \mathrm{P}), 9.5$ in the experimental animals, to be contrasted with the $12 \cdot 1$ in the controls, a statistically significant difference $(P<0.001)$.

The evidence of placental compensatory hypertrophy, induced by ovariectomy in pregnant rats is of considerable obstetric significance. Clinical evidence indicates that over-sized placentae in the human prolong pregnancy (Adair \& Therelander, 1925), increase the incidence of uterine inertia (Timonen, Vara, Lokki \& Hirvonen, 1965) and protracted labour (Reenkola, 1948) and post partum haemorrhage (Timonen et al., 1965). The concept which readily incorporates these experimental and clinical findings is the 'local' effect of placental pro- 
gesterone, imposing an asymmetric 'block' on the uteri of those species which are largely placental- rather than luteal-controlled at the end of pregnancy (Csapo, 1961).

The authors are grateful to Professor Arpad Csapo for his advice during the course of the experiments and the preparation of the manuscript. The technical assistance of Barbara Green is appreciated.

This work was supported by the National Institutes of Health, U.S. Public Health Service Grant HD01478 and by the Sunnen Foundation.

\section{REFERENCES}

Adair, F. L. \& Therelander, H. (1925) A study of the weight and dimensions of the human placenta, in its relation to the weight of the newborn infant. Am. F. Obstet. Gynec. 10, 172.

Csapo, A. (1961) Defence mechanism of pregnancy. In: Progesterone and the Defence Mechanism of Pregnancy. Ciba Foundation Study Group No. 9, p. 3. Churchill, London.

Csapo, A. (1967) The ovariectomy syndrome and the initiation of labor. Int. Symp. Prenatal Life, Detroit. Charles C. Thomas, Springfield, Ill. (In press).

Csapo, A. \& CsApo, E. (1968) The luteo-placental shift, the guardian of prenatal life. Nature, Lond. (In press).

Reenkola, M. (1948) Untersuchungen über den Partus Serotinus. Acta obstet. gynec. scand. 28, Suppl. 3. Reynolds, S. R. M. (1949) Physiology of the uterus, 2nd edn. Hoeber, New York.

Timonen, S., Vara, P., Lokki, O. \& Hirvonen, E. (1965) Duration of pregnancy. Annls Chir. Gynaec. Fenn. 54, Suppl. 141.

VAN Der Vies, J. \& FEenstra, H. (1967) The effects of ovarian hormones on the placenta of rats. Acta endocr., Copenh. Suppl. 119, 235.

WeNor, G. G. (1952) Der Wassergehalt des Hypertrophierenden Muskels. Gegenbaurs morph. Jb. 92, 459. 